\title{
Stem cell therapies for autoimmune hepatitis
}

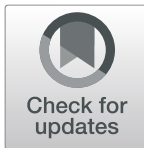

\author{
Ahmed Lotfy ${ }^{1 *+}$ (D) Aya Elgamal ${ }^{2+}$, Anna Burdzinska ${ }^{3}$, Ayman A. Swelum ${ }^{4,5}$, Reham Soliman ${ }^{6,7}$, \\ Ayman A. Hassan ${ }^{7}$ and Gamal Shiha ${ }^{7,8^{*}}$
}

\begin{abstract}
Autoimmune hepatitis is a chronic inflammatory hepatic disorder which may cause liver fibrosis. Appropriate treatment of autoimmune hepatitis is therefore important. Adult stem cells have been investigated as therapies for a variety of disorders in latest years. Hematopoietic stem cells (HSCs) were the first known adult stem cells (ASCs) and can give rise to all of the cell types in the blood and immune system. Originally, HSC transplantation was served as a therapy for hematological malignancies, but more recently researchers have found the treatment to have positive effects in autoimmune diseases such as multiple sclerosis. Mesenchymal stem cells (MSCs) are ASCs which can be extracted from different tissues, such as bone marrow, adipose tissue, umbilical cord, and dental pulp. MSCs interact with several immune response pathways either by direct cell-to-cell interactions or by the secretion of soluble factors. These characteristics make MSCs potentially valuable as a therapy for autoimmune diseases. Both ASC and ASC-derived exosomes have been investigated as a therapy for autoimmune hepatitis. This review aims to summarize studies focused on the effects of ASCs and their products on autoimmune hepatitis.
\end{abstract}

Keywords: Stem cells, Autoimmune hepatitis, Mesenchymal stem cell, Hematopoietic stem cells, Exosomes, Mesenchymal stromal cell

\section{Introduction}

Liver is one of the main effector sites of numerous systemic immune reactions that can lead to variable chronic and autoimmune disorders. Examples of autoimmune liver diseases (AILDs) are autoimmune hepatitis (AIH), IgG4-related sclerosing cholangitis, primary biliary cholangitis, and primary sclerosing cholangitis. These diseases can lead to hepatic dysfunctions including cholestasis, fibrosis, cirrhosis, and even liver cancer [1].

For chronic hepatic disorder, stem cell therapy seems to be a safe and effective treatment choice [2, 3].

\footnotetext{
*Correspondence: Lotfy_bio@hotmail.com; ahmed.lotfy@psas.bsu.edu.eg; G_shiha@hotmail.com

${ }^{\dagger}$ Ahmed Lotfy and Aya Elgamal contributed equally to this work.

${ }^{1}$ Biotechnology and Life Sciences Department, Faculty of Postgraduate Studies for Advanced Sciences (PSAS), Beni-Suef University, Beni-Suef 62511, Egypt

${ }^{7}$ Egyptian Liver Research Institute and Hospital (ELRIAH), Mansoura, Egypt Full list of author information is available at the end of the article
}

Mesenchymal stem cells (MSCs) therapy possess numerous advantageous properties such as multipotential for differentiation, anti-fibrosis properties, and immunomodulatory effects [4]. Numerous investigations have shown that MSC therapy in AILDs is both safe and effective. Hematopoietic stem cells (HSCs) which are another type of stem cells have also a therapeutic capability. HSCs transplantation have been applied in several autoimmune diseases [5].

Many previous reviews are focused on the stem cell as a treatment for chronic hepatic disorders or acute-onchronic liver failure $[2,6]$. The current review aimed to summarize studies focused on the effects of ASCs and their products on autoimmune hepatitis.

\section{Autoimmune hepatitis}

Autoimmune hepatitis (AIH) is one of the chronic hepatic disorders believed to be induced by a loss of

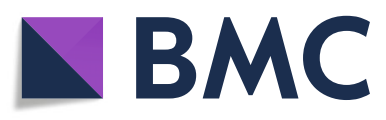

(c) The Author(s). 2021 Open Access This article is licensed under a Creative Commons Attribution 4.0 International License, which permits use, sharing, adaptation, distribution and reproduction in any medium or format, as long as you give appropriate credit to the original author(s) and the source, provide a link to the Creative Commons licence, and indicate if changes were made. The images or other third party material in this article are included in the article's Creative Commons licence, unless indicated otherwise in a credit line to the material. If material is not included in the article's Creative Commons licence and your intended use is not permitted by statutory regulation or exceeds the permitted use, you will need to obtain permission directly from the copyright holder. To view a copy of this licence, visit http://creativecommons.org/licenses/by/4.0/ The Creative Commons Public Domain Dedication waiver (http://creativecommons.org/publicdomain/zero/1.0/) applies to the data made available in this article, unless otherwise stated in a credit line to the data. 
tolerance to autoantigens specific to hepatocytes, and characterized by elevations of the levels of alanine aminotransferase (ALT), aspartate aminotransferase (AST), and immunoglobulins, particularly IgG, in the serum. The latter is used to determine biochemical remission [7]. Autoantibodies, including antinuclear antibodies (ANAs), smooth muscle antibodies, anti-liver kidney microsomal type 1 (anti-LKM1), and anti-cytochrome P4502D6 antibodies can be identified in the serum of people suffering from $\mathrm{AIH}[8]$.

Hepatic injury caused by inflammation [9], as well as various non-AIH-specific features such as lymphoplasmacytic infiltrations, hepatocyte resetting, and emperipolesis, are all important characteristics of AIH [10]

Besides plasma cells producing autoantibodies, the cytotoxic $\mathrm{T}$ cells specific to hepatocyte-expressed antigens were demonstrated to play an important role in the accelerating the hepatic damage during the course of AIH. The proposed cellular mechanisms behind the breaking of immune tolerance in $\mathrm{AIH}$ include the increased number of Th17 cells and defects in T regulatory cells activity.

Although the specific cause of AIH is unidentified, studies throughout the latter four decades have shown that the etiology of the diseases in both adult and juvenile is influenced by interconnections among genetic and environmental factors. Molecular mimicry, immunological activation in response to self-antigen presentation, and loss of self-tolerance are examples of these interactions as described in detail by Mieli-Vergani et al. [11].

Although the use of corticosteroids is the common treatment for $\mathrm{AIH}$, some patients with disease react badly to such treatment, and some recovered patients may face severe adverse effects or recurrence following discontinuing steroid use [12]. For these reasons, novel therapies are needed.

There are several AIH animal models produced to enable studying the hepatic immunity and pathological pathways of the disease (Fig. 1). AIH models include spontaneous models, models induced by surrogate antigens (including hepatitis induced by concanavalin A and $\alpha$-galactosylceramide), and models induced by liver autoantigens (including hepatitis induced by liver homogenate, liver autoantigen, and mouse hepatic virus A59 infection) [13].

Concanavalin A (ConA) activates antigen non-specific $\mathrm{T}$ lymphocytes and macrophages resulting in acute immune-mediated liver damage [14]. Hepatic aggregation of Con A and its binding to mannose-rich glycoproteins on liver sinusoidal endothelial cells (LSECs) and Kupffer cells causes $\mathrm{T}$ cells to go into a cellular arrest. $\mathrm{T}$ cells, particularly NKT cells, produce inflammatory cytokines (e.g., IFN- $\gamma$ and TNF- $\alpha$ ), which activate other cells and cause apoptosis in LSECs and hepatocytes [15]. TNF receptors on hepatocytes may be upregulated by IFN- $\gamma$, resulting in fragmentation of the DNA and liver toxicity [16].

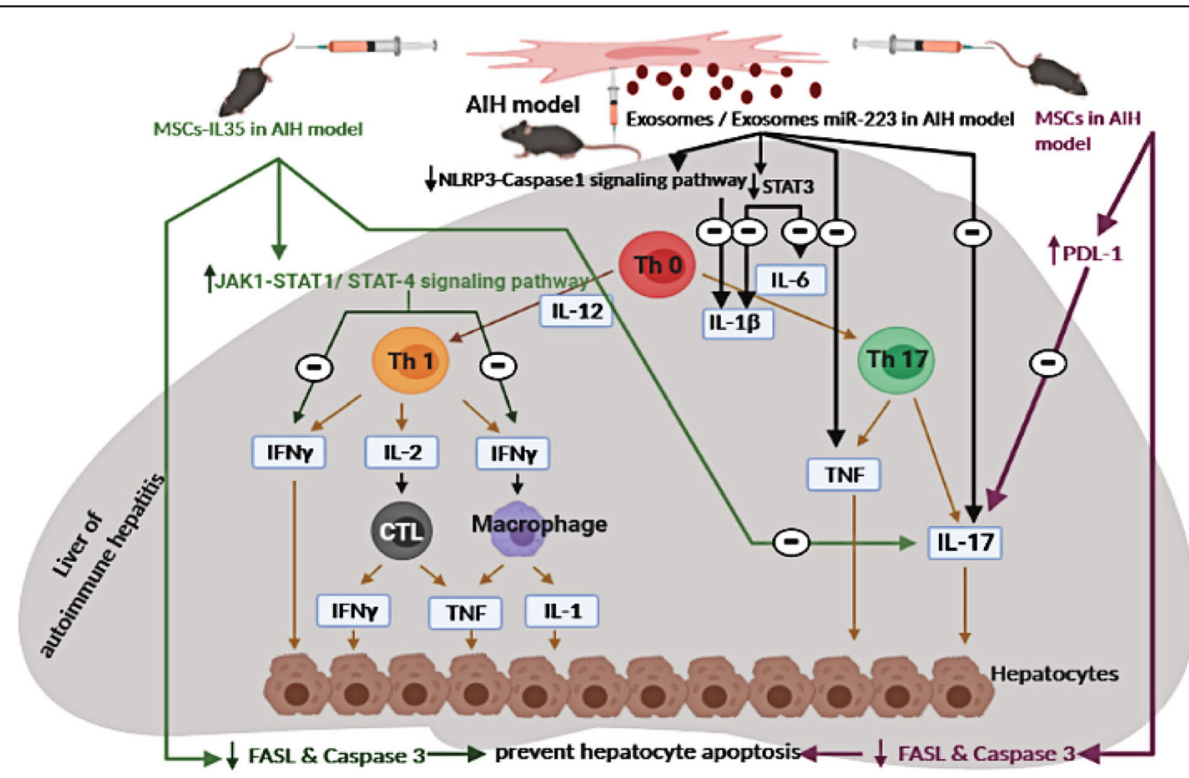

Fig. 1 Postulated immunomodulatory role of MSCs, modified MSCs, and their exosomes in an AlH animal model. AlH, autoimmune hepatitis; Th17, T helper 17 cells; IL, interleukin; CTL, cytotoxic CD8+ T lymphocyte; JAK, Janus kinase; STAT, signal transducer and activator of transcription; FASL, Fas ligand; IFN-ץ, interferon-gamma; PD-L1, the ligand of PD-1 "programmed death-1"; TNF, tumor necrosis factor; NLRP3, nucleotidebinding domain-like receptor protein 3. The figure was created using the images from Servier Medical Art 
The use of liver extracts can cause pathological symptoms of AIH. As mouse model, a monthly injection of syngeneic liver homogenate with Klebsiella pneumoniae polysaccharide as adjuvant causes infiltration of primarily lymphocytes, in portal regions and piecemeal necrosis [17]. A different model is developed by intraperitoneal injection of mice with syngeneic liver homogenate (S100) with Freund's adjuvant. This results in inflammatory infiltrates and liver cell necrosis as well as production of S-100 protein-specific T cells [18].

\section{Stem cells}

Stem cells are undifferentiated cells which have the ability to self-renew and to differentiate into specialized cell types [19]. Stem cells are classified based on their potency, into totipotent, pluripotent, multipotent, and unipotent stem cells. Stem cells are moreover divided into groups based on their origin into embryonic, fetal, umbilical cord (infant), adult, and induced pluripotent stem cells [20].

Stem cells are needed for the maintenance of homeostasis in tissues. They are usually in a quiescent state, and preserve their progenitor properties by selfrenewing. Stimulation with extrinsic factors or damaged host cells activates stem cells to proliferate and differentiate, to renew the injured tissue. Stem cells are now also believed to actively interact with the tissue microenvironment, especially with components of the immune system [19].

\section{Mesenchymal stem cells}

Mesenchymal stem cells (MSCs) are attracting a lot of attention because of their relative ease of isolation, extensive capacity for expansion, and capability of differentiation into multiple types of cell principally osteoblasts, chondrocytes, and adipocytes [21, 22]. MSCs have the potential to modify tissue regeneration and influence different immune problems, due to their immunoregulatory activity. MSCs have been reported to affect the behavior of different immune cells. In regards to the potential treatment of autoimmune diseases, including $\mathrm{AIH}$, the most important features of MSCs seem to be the capability to suppress the activation and proliferation of lymphocytes and the promotion of Tregs formation. These abilities have been related to the expression/secretion of several molecules by MSCs: CTLA-4 (cytotoxic T cell antigen 4), PD-L1 (ligand for programmed cell death protein 1), IDO-1 (indoleamine 2,3-dioxygenase 1), FasL (Fas ligand) iNOS (inducible nitric oxide synthase), TGF- $\beta$ (transforming growth factor beta), and PGE2 (prostaglandin E2).

The inhibitory receptor - CTLA4 - was shown to be expressed by human MSCs both in cell surface and secretory form [23]. It is known that the inhibition of lymphocytes activation via CTLA4 is an important mechanism to maintain immune self-tolerance. It was suggested that mutations in CTLA4 may contribute to the autoimmune hepatitis-like condition [24]. Human MSCs additionally express PD-L1 which is a ligand for PD-1 - an inhibitory receptor expressed on lymphocytes. Similarly to CTLA-4, MSCs express PD-L1 in both cell surface and secreted form [25]. The next factor which is believed to be responsible for suppressive effect of MSCs on lymphocytes is IDO-1, the enzyme converting tryptophan to kynurenine. Tryptophan is necessary for proper T cells function. IDO antagonist used in vitro diminished significantly suppressive effect of hMSCs on lymphocytes [26]. Additionally, it was postulated that IDO was one of key molecules responsible for therapeutic effect of MSCs administrated in colitis in mice model [27]. MSCs additionally express iNOS and FasL which also take part in their suppressive effect on lymphocytes. Inducible NOS generate nitric oxide (NO) which possess well known inhibitory impact on $\mathrm{T}$ cells by suppressing IL-2 pathways and inducing $\mathrm{T}$ cell apoptosis [28]. The Fas-FasL interaction is another axis crucial for controlling the lymphocytes number. The dysfunction of this mechanism leads to the autoimmune lymphoproliferative syndrome. It was shown that FasL expression mediates the suppressive effect of MSCs on the growth of multiply myeloma (plasma cells) in a mice model [29].

The expression of all these factors by MSCs results in their remarkable capability to suppress the activation and proliferation of lymphocytes which is a strong basis for their use in therapy of autoimmune diseases. In addition, while MSCs generally inhibit lymphocyte activity, they have been shown to promote a tolerogenic Treg population [30]. T regulatory cells are essential in maintaining peripheral self-tolerance. The effect of MSCs on Tregs differentiation can be either direct [31] or via switching monocytes toward anti-inflammatory macrophages [32]. It is believed that the process is mediated mainly through the secretion of TGF $\beta$ and PGE2, factors produced by MSCs in significant amounts. Moreover, PGE2 was also shown to take part in inhibiting the formation of Th17 subset under the influence of MSCs [33] which further support the tolerogenic influence of this population.

It is worth to underline that the expression of above described molecules by MSCs is significantly increased in pro-inflammatory environment. In vitro, it is stimulated by the addition of cytokines like IFN- $\gamma$ and TNF- $\alpha$ and/or poly(I:C) - a ligand of TLR3 (toll-like receptor 3 ). This feature seems to be very promising in terms of potential therapeutic use in autoimmune diseases MSCs would turn on their immunosuppressive activity in inflamed tissues. 
MSCs are also able to interact with other immune cells, such as macrophages, natural killer cells, dendritic cells (DCs), neutrophils, and mast cells. All together, these interactions can promote tolerogenic activity of the immune system, thus facilitating the beneficial effect in various autoimmune disorders, as previously described [34-37]. Multiple studies have shown the remarkable immunomodulatory capacity of MSCs, and the ability of infused MSCs to suppress excessive inflammatory process and to promote tissue regeneration in various models of disorders such as graft-versus-host disease (GvHD) [38], rheumatoid arthritis [37], and multiple sclerosis [39]. However, the immunological status of the local environment and presence or absence of certain stimuli affects the ability MSCs to modulate the inflammatory process [19]. Unfortunately, there are also reports indicating that MSCs may enhance the growth of some tumors [40]. These data are in agreement with MSC tolerogenic and proangiogenic activity. Therefore, for upcoming clinical trials, short- and long-term side effects must be carefully observed and timely addressed.

\section{MSC gene modifications}

Owing to the features described in Section 3.1, MSC therapies have attracted considerable attention for several decades from researchers interested in the treatment of various diseases [41]. The functionality of MSCs can be increased by transforming them with genes that enhance their therapeutic potential. Previous studies have shown that MSC gene modifications, including the integration of exogenous genes such as hepatocyte growth factor [42], IL-7 [43], IL-10 [44], and Foxp3 [45] successfully improve the therapeutic performance of MSCs. MSCs with the IL-35 gene integrated into the genome (IL-35-MSCs) can successfully suppress the proliferation and functionality of $\mathrm{CD} 4+\mathrm{T}$ cells in vitro [50].

\section{Exosomes}

Exosomes are described as lipid bilayer-encased membrane vesicles less than $150 \mathrm{~nm}$. Almost all types of cells secrete them, and they can transmit bioactive substances such as proteins, mRNAs, and microRNAs, from one cell to another [51, 52]. MSC-exosomes could be used to reduce the adverse effects caused by the administration of MSCs, such as tumorigenesis, toxicity, undesired immune responses, and formation of emboli [53, 54]. Exosomes have been shown to modulate inflammation in many studies [55]. Exosomes are important effectors of the paracrine activity of BMSCs, and exosomes produced from BMSCs have been found to enhance recovery in animal models of GvHD and drug-induced liver injury according to recent research $[56,57]$. In experimental animal models of autoimmune uveoretinitis, MSCexosomes suppressed Th17 differentiation and lowered
IL-17 secretion [58]. The functionality of exosomes can be expanded to the areas of immunology, neurobiology, stem cell biology, and tumor biology [59].

\section{Hematopoietic stem cells}

Hematopoietic stem cells (HSCs) are multipotent stem cells that can differentiate into all blood cell types [60]. In human at adult stage, HSCs are found mainly in bone marrow, less in peripheral blood, and in umbilical cord blood during pregnancy. The proliferation of HSCs results in generation of both: precursors for all blood cell lineages and cells which maintain their undifferentiated state [61].

For serious and treatment-refractory autoimmune problems, hematopoietic stem cell transplantation (HSCT) has become as a viable therapy. The pathogenesis of autoimmune diseases is currently attributed to the incorrect identification of self-antigens by $\mathrm{T}$ and $\mathrm{B}$ cells causing cell-mediated or humoral reactions, or both, and resulting in inflammatory tissue and vascular damage [62]. HSCT is used to eliminate autoreactive immune cells and recreate a naive, self-tolerant immune system in patients with autoimmune disorders [63].

Multiple sclerosis, systemic sclerosis, and rheumatoid arthritis are among the autoimmune illnesses for which HSCT is a treatment option [64]. The American Society for Blood and Marrow Transplantation (ASBMT) stated that HSCT is approved as a "standard of care, clinical evidence available" for diseased people with treatmentrefractory relapsing MS [65]. HSCT is indicated as a "standard of care" for individuals suffering from severe systemic sclerosis in the ASBMT position statement [66].

Anti-thymocyte globulin, along with either high dosage Cyc or other chemotherapeutic drugs, is the most common conditioning protocol applied in people with AIH indicated for autologous HSCT [64]. Following conditioning, autologous (CD34+) stem cells are infused. After their neutrophil count has been recovered, patients may be allowed to leave the hospital which typically occurs within one to three weeks following the stem cell administration. From many months following HSCT, majority of patients stay significantly lymphopenic, until their immune system is completely reconstituted [67].

In an autologous graft, stem cell mobilization, conditioning, and T-cell depletion is linked to a higher risk of infection [64]. Autoimmune disorder can develop de novo during immune recovery after HSCT, due to impaired functioning of mechanisms building immune selftolerance. At 5 years following HSCT, the cumulative rate of recurrent autoimmune disease was observed to be $9.8 \%$ [68]. EBMT registry information has been analyzed and revealed that relapse of the disease following HSCT is an ongoing problem [69]. 


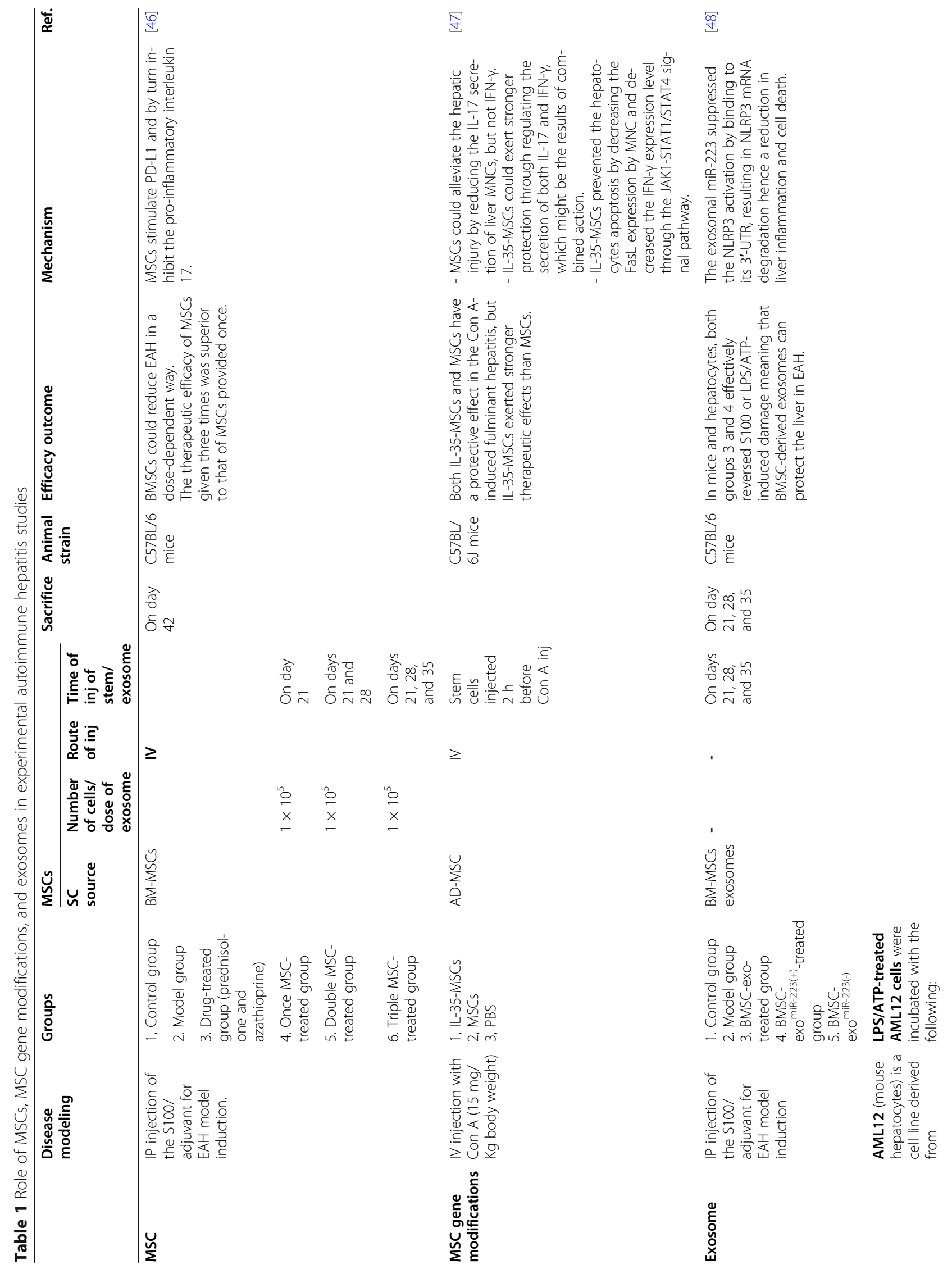




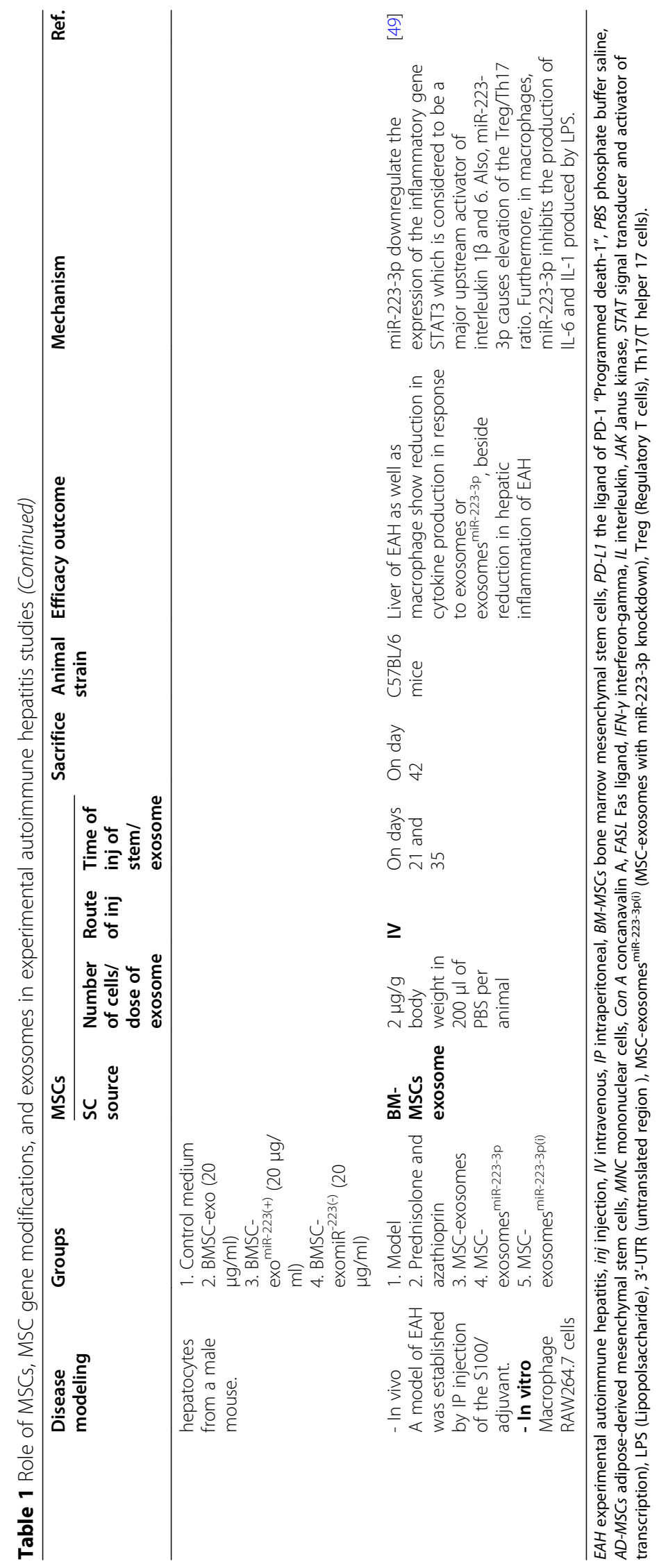


Despite the important role of stem cells in immune modulation, there are a few studies investigating the effects of stem cells on $\mathrm{AIH}$, as summarized below.

\section{Stem cells and AlH studies \\ Experimental autoimmune hepatitis (EAH) studies MSCs and experimental autoimmune hepatitis}

Chen et al. [46] tested the effects of different treatments in a mouse model of EAH. One group received three treatments of BMSCs, one group was treated twice with BMSCs, one was treated once with MSCs, and a group was treated with prednisolone and azathioprine. The model was established using intraperitoneal (IP) injection of the S100/adjuvant in C57BL/6 mice. Mice which underwent the induction of EAH with no subsequent treatment constituted control "model group". The researchers found that administration of culture-expanded BMSCs can alleviate EAH in a dose-dependent way, and the therapeutic effect observed in the group that received an intravenous (IV) injection of $1 \times 10^{5}$ BMSCs three times was better than single injection.

BMSC-treated groups showed a decrease in ALT and AST serum levels compared to the model group, and the treatment significantly alleviated the lymphocyte infiltration and the occurrence of intra-lobular inflammatory lesions and necrosis. The PD-L1 in EAH mouse livers was upregulated compared with the control group and was reversed in drug-treated and BMSC single-treatment groups. PD-L1 was considerably more elevated in the group that received MSCs in a triple manner than in the group that received MSCs only once. The increased PDL1 expression corresponded with the reduced inflammation and tissue damage. The expression of interleukin 17 was elevated in EAH mice and gradually decreased over time, following MSC transplant. This trend was contrary to natural tendency of variation of PD-L1, revealing that MSCs stimulate PD-L1 that suppresses interleukin 17 production. In the model group, IL-17 levels were also increased, showing that it played a pro-inflammatory role in $\mathrm{EAH}$ mice and that pro-inflammatory and antiinflammatory actions were present in EAH animals.

Chen et al. [46] concluded that BMSCs inhibited the immune response in their experiment by stimulating the inhibitory factor PD-L1 which subsequent inhibit the proinflammatory interleukin 17. PD-1 and PD-L1 negative co-stimulatory binding interferes with CD28-mediated PI3K activation which blocks the Akt phosphorylation, reducing T-cell multiplication and maintenance and glucose metabolism as well as cytokines synthesizing (Fig. 1) [70].

\section{MSC gene modifications and experimental autoimmune hepatitis}

Regulatory $\mathrm{T}$ (Treg) cells are a subset of CD4+ T lymphocytes that are necessary for keeping immune self- tolerance. IL-35 is a member of the IL-12 family of heterodimeric cytokines. It is generated by Treg cells and is needed for maximal suppressive activity in Tregs [71]. In contrast to the other IL-12 family members, IL-12 and IL-23, IL-35 appears to have a strictly regulatory function. The primary physiological role of IL-35 is to regulate $\mathrm{T}$-cell homeostasis, by inhibiting the polarization of $\mathrm{T}$ helper (Th) 2 and Th17 cells [72]. IL-35 have antiinflammatory role in autoimmune diseases such as EAE and CIA [73, 74]. However, the physiological impact of IL-35 on concanavalin A (Con A)-induced hepatitis was not known until Wang et al. [47] investigated the effect of IL-35 gene-programmed MSCs in preventing Con Ainduced liver injury. Con A-induced hepatitis is a wellstudied murine model that largely reflects human $\mathrm{AIH}$ disease [14].

Wang et al. [47] reported that both IL-35 genemodified MSCs (IL-35-MSCs) and adipose-derived MSCs have a protecting effect in Con A-induced fulminant hepatitis in C57BL/6J mice. Hepatitis was induced by the IV injection of $15 \mathrm{mg} / \mathrm{Kg}$ body weight Con A $2 \mathrm{~h}$ after the administration of MSCs. IL-35-MSCs exerted therapeutic impact more powerful than adipose-derived MSCs (Fig. 1).

A survival study was carried out, in which the dosage of Con A was elevated to $20 \mathrm{mg} / \mathrm{Kg}$ body weight. In this experiment all of the IL-35-MSC-transplanted mice survived throughout the whole period of observation, while the PBS-treated animals died within 24 h. The survival rate of mice transplanted with MSCs amounted $40 \%$. Administrated IL-35-MSCs were able to migrate to the damaged liver tissues in a more targeted manner than the MSC- and PBS-treated groups. In both IL-35-MSCs, which had the best treatment effect, and MSCs, the area of liver necrosis was reduced, the expression level of active caspase3 was reduced, and the Fas ligand (FasL) mRNA level of mononuclear cells (MNC) was decreased. The IFN- $\gamma$ expression level in the hepatic MNCs and liver tissue showed a significant decrease in the IL-35-MSC-transplanted group, in comparison to the MSC and PBS groups. The IL-17 expression level in the hepatic MNCs and liver tissue was significantly decreased in both the IL-35-MSC- and MSC-treatment groups, and the differences between them were insignificant. There were no significant differences in the expression levels of TNF- $\alpha$, IL-4, IL-2, and IL-12 in hepatic MNCs. The expression of the proteins JAK1, STAT1, and STAT4 was significantly increased in the IL-35MSC-treated groups compared with the pure MSCs and the PBS control groups. The amount of protein expression was increased significantly after phosphorylation. There was no significant difference and no obvious detection of PJAK2 among the three groups. 
Wang et al. [47] found that MSCs could alleviate liver injury by reducing the secretion of IL-17, but not IFN- $\gamma$, by liver MNCs, while IL-35-MSCs exerted stronger effects by regulating the secretion of both IL-17 and IFN$\gamma$. IL-35-MSCs prevented the apoptosis of hepatocytes by reducing the expression of FasL by MNC and decreased the level of expression of IFN- $\gamma$ via the JAK1STAT1/STAT4 signal pathway (Fig. 1).

\section{Exosomes and experimental autoimmune hepatitis}

Two experiments have been conducted using MSCderived exosomes as a therapy for EAH [48, 49]. In the first experiment Chen et al. [48] studied the effect of IV injection of BMSC-derived exosomes and exosomes isolated from BMSCs transfected with miR-223 (BMSCexo $^{\text {miR-223(+) }}$ ) in an EAH model established by IP injection of C57BL/6 mice with the S100/adjuvant and in LPS/ATP-treated AML12 cells. They reported that both BMSC-exo and BMSC-exo ${ }^{\text {miR-223(+) }}$ reversed both S100and LPS/ATP-induced damage both in animals and in liver cells, indicating that BMSC-derived exosomes can protect liver injury in $\mathrm{AIH}$ animal model. Their result indicated that mice treated with either BMSC-exo or BMSC-exo ${ }^{\text {miR-223(+) }}$ exhibit increased amount of miR223 in hepatic tissue and displayed significantly better liver structure. Additionally, Chen et al. reported a significant decrease in serum levels of ALT and AST (greater using BMSC-exo ${ }^{\text {miR-223(+) }}$ ), significant decreases in levels of the pro-inflammatory cytokines TNF-a, IL$17 \mathrm{~A}$, and IL-1 $\beta$ in serum, and mRNA levels in the liver with a more pronounced difference in BMSCexo $^{\text {miR-223(+) }}$ treated mice, and a significant reduction in protein and mRNA expression of NLRP3 and caspase-1 in the liver.

They also found that in vitro PKH67-labeled exosomes were up-taken and transported to the cytoplasm compartments, and miR-223 in AML12 cells increased when co-cultured with MSC-exo or MSC-exo ${ }^{\text {miR-223(+) }}$. Cotreatment with LPS and ATP substantially upregulated the expression of NLRP3, caspase-1, and IL- $1 \beta$. The IL$1 \beta$ level reduced in the MSC-exo group, with the MSCexo $^{\text {miR-223(+) }}$ group showing the greatest reduction. In comparison to the model group, the NLRP3 level and the caspase- 1 level dropped. LPS and ATP caused severe damage to AML12 hepatocytes, while MSC-exo and MSC-exomiR $^{-223(+)}$ saved cells from death caused by LPS and ATP.

The NLRP3-caspase-1 signaling pathway may be involved in the mechanism behind these findings. Exosomal miR-223 bound to NLRP3's 3'-UTR and inhibits its activation, resulting in the degradation of NLRP3 mRNA and the suppression of liver inflammation and cell elimination. During the activation of NLRP3, inactive procaspase-1 is cleaved into p20 and p10 subunits, causing the maturation and production of IL-1 $\beta$. As well as secreting pro-inflammatory cytokines, caspase-1 elicits a novel kind of inflammatory cell death, called pyroptosis [75]. Cell membrane rupture and the release of pro-inflammatory cellular contents are associated with pyroptosis, which is dependent on caspase- 1 activation. In response to internal or external danger signals, it is thought to be a critical element in innate immune response, activating caspase- 1 and producing interleukin IL-1 $\beta$ [76]. Many researchers have indicated that abnormal NLRP3 activation contributes to autoimmune disorders development [77, 78].

In the second experiment, Lu et al. [49] studied the effect of IV injection of BMSC-derived exosomes without modification and transfected with miR-223-3p (BMSCexo miR-223-3p $)$ in an EAH model and in LPS-treated macrophage RAW264.7 cells. miR-223-3p (is an earlier name after the old synonyms miR-223 or the guide strand) was successfully incorporated into MSCexosomes and delivered miR-223-3p into macrophages. The exosomes had no toxic effect on the macrophages and either the application of exosomes or exosomes with miR-223-3p improved the inflammatory responses in the $\mathrm{EAH}$ and lowered the release of inflammatory cytokines in both the liver and macrophages.

In response to injection of MSC-exosomes or MSCexosomes $^{\text {miR-223-3p }}$, dramatically there was improvement revealed by reduction in the infiltration of MNC into the centrilobular or portal areas, besides reduction in the levels of liver enzymes and inflammatory lesions. The results of serum analysis to the levels of some interleukins in response to the exosomes therapy show significant lowering in the levels of interleukin $1 \beta, 6$, and 17 and dramatic increasing in interleukin 10 in comparison to treatment with PBS or MSC-exsomes ${ }^{\text {miR-223-3p(i) }}$ (MSCexosomes with miR-223-3p knockdown).

MSC-exosomes and MSC-exosomes ${ }^{\text {miR-223-3p }}$ were capable of reducing the proportions of Th17 cell while increasing Treg cell proportions. The Treg/Th17 ratio was significantly reduced in the EAH induced mice, but the ratio returned to normal after treatment with MSCexosomes.

Macrophages engulfed MSC-exosomes that was tagged with GFP in vitro. At mRNA and protein levels there was reduction in the levels of interleukins $1 \beta$ and 6 which was induced previously by LPS, after treatment with either MSC-exosomes or MSCexosomes $^{\text {miR-223-3p }}$. The authors hypothesized that the mechanism of improvement induced by BMSC-exo and BMSC-exo miR-223-3p could possibly being linked to miR-223-3p, which negatively modulates the expression of the inflammation-related gene STAT3, which has been identified as a key activator of interleukin $1 \beta$ and 6 . 
Both IL- $1 \beta$ and IL-6 are involved in AIH. IL-6 has been shown to stimulate the differentiation of naïve $\mathrm{T}$ lymphocytes into Th17 cells $[79,80]$, which release IL17 and aid in the progression of AIH [81]. Human Treg cells can be converted to Th17 cells by IL-1 $\beta$ [82]. T regulatory cells play a critical immune role via secretion of interleukin 10 which keep immune homeostasis and tolerance in the liver [83]. In experimental $\mathrm{AIH}$, there was elevation in both $\mathrm{T}$ regulatory and $\mathrm{T}$ helper 17 cells and their secretions interleukin 10 and 17 while the ratio of $\mathrm{T}$ regulatory/ $\mathrm{T}$ helper 17 was much lower [84-88]. STAT3 stimulates RORt and increases interleukin 17 release in $\mathrm{T}$ helper 17 cells, which has important role in autoimmune disease [58].

In summary, it has been shown that MSCs provide a therapeutic effect in AIH animal models. EAH had been alleviated by the administration of BMSCs in a dosedependent way and this was explained that BMSCs had upregulated PD-L1 and inhibited IL-17. MSCs have been genetically modified with IL-35 to increase their efficacy by preventing the hepatocytes apoptosis by lowering the expression of FasL by mononuclear cells (MNC) and decreased IFN- expression level through the JAK1STAT1/STAT4 signal pathway. Moreover, the BMSCderived exosomes showed a promising therapeutic effect either containing additional miRs or none by inhibition of inflammatory cytokines (Fig. 1, Table 1).

\section{Case reports}

Hematopoietic stem cell transplantation and $\mathrm{AlH}$ [89]

Calore et al. [89] reported that AIH could be cured with allogeneic HSCT (Table 2). This finding is particularly important for patients who have both $\mathrm{AIH}$ and a hematological illness at the same time. These researchers had a patient who was diagnosed with $\mathrm{Hb}$ SS sickle cell disease (SCD) as a 4-year-old girl, when she was hospitalized because of severe hemolytic anemia. At the age of 13 years, the patient was diagnosed with AIH type I, when hospitalized for cholestatic jaundice and elevation of liver enzymes. The diagnosis was done by liver histology, which revealed portal and peri-portal fibrosis, portal inflammatory infiltrates primarily composed of lymphocytes and plasma cells, and focal areas of necrosis. Steroids were limited and withdrawn 5 months after the AIH was diagnosed but had to be restarted 1 month later due to a relapse. Four years later, the patient had another two relapses of $\mathrm{AIH}$, indicating that constant immunosuppression with steroids was needed. During the follow-up, the antinuclear and anti-smooth muscle autoantibodies were still detected as positive, with a varying titer related to disease activity. Exchange transfusions were conducted every $18-20$ days due to the appearance of repeated and severe vaso-occlusive crises while being administrated steroids.

After conditioning with a combination of treosulfan, fludarabine, and Graphalon ${ }^{\circ}$ anti-thymocyte globulins, the patient had HSCT at the age of sixteen. The intensive transfusion program necessary to control the cerebrovascular disease, and the recurrent vasoocclusive crises were the main indication for HSCT. No post-transplant immune suppression was used, and all AIH therapies were stopped before conditioning began. The patient's HbSA haploidentical father was used as a donor, and an ex-vivo $\operatorname{TCR} \alpha \beta$ and CD19 depletion of PB stem cells was performed [91].

Table 2 Showing the role of HSCT and BMT in AlH

\begin{tabular}{|c|c|c|c|c|c|c|}
\hline & $\begin{array}{l}\text { Patient main } \\
\text { disorder }\end{array}$ & $\begin{array}{l}\text { Patient } \\
\text { gender }\end{array}$ & Donor & Transplanted cells & Results & Ref. \\
\hline HSCT & $\begin{array}{l}\text { patient with SCD } \\
\text { and } \mathrm{AlH}\end{array}$ & Female & $\begin{array}{l}\text { Patient's HbSA haploidentical } \\
\text { father }\end{array}$ & $\mathrm{HSCT}$ & $\begin{array}{l}\text { - After HSCT by } \mathbf{2} \text { years, the data } \\
\text { showed a full donor hematopoiesis, } \\
\text { no SCD manifestation was noted, } \\
\text { cerebral vasculopathy appeared to be } \\
\text { resolved and the patient required no } \\
\text { additional medical treatment. } \\
\text { Antinuclear and anti-smooth muscle } \\
\text { autoantibodies were negative } 2 \\
\text { months after HSCT, and there was no } \\
\text { recurrence of AlH in the patient. }\end{array}$ & {$[89]$} \\
\hline BMT & $\begin{array}{l}\text { Patient with a 4- } \\
\text { year history of } \\
\text { AlH and devel- } \\
\text { oped acute AL- } \\
\text { L2. }\end{array}$ & Male & $\begin{array}{l}\text { His healthy } 25-y e a r-o l d ~ s i b l i n g \\
\text { was chosen as an MLC-non- } \\
\text { reactive BM donor who was } \\
\text { HLA A-, HLA B-, and DR- } \\
\text { matched }\end{array}$ & $\begin{array}{l}-6.8 \times 10^{8} \text { bone marrow cells } \\
\text { for each kilogram (overall } 4.7 \\
\times 10^{10} \text { cells) } \\
-10^{5} \mathrm{~T} \text { lymphocytes for each } \\
\text { kilogram body from a } \\
\text { donor's peripheral blood } \\
\text { (overall of } 69 \times 10^{5} \mathrm{~T} \\
\text { lymphocytes) }\end{array}$ & $\begin{array}{l}\text { - Allogeneic transplantation of BM and } \\
\text { donor T cells resulted in the } \\
\text { normalization of T-cell responses to } \\
\text { ASGPR, the elimination of antibodies } \\
\text { to the same autoantigen, and the no- } \\
\text { ticeable treatment of } \mathrm{AlH} \text {. }\end{array}$ & {$[90]$} \\
\hline
\end{tabular}

AlH autoimmune hepatitis, SCD sickle cell disease, TCRaß T cell receptor, PBSC peripheral blood stem cell, HSCT hematopoietic stem cell transplantation, GvHD graft-versus-host disease, $A L-L 2$ acute lymphoblastic leukemia, $H L A$ human leukocyte antigen, $M L C$ mixed leukocytes culture, $B M T$ bone marrow transplantation, ASGPR antiasialoglycoprotein receptor 
The patient developed a fever, stomach pain, and anorexia on day 35 after undergoing HSCT and was diagnosed with grade II acute GvHD. She was treated with cyclosporine and extracorporeal photochemotherapy, and within a week, the symptoms were completely gone. Two years after HSCT, chimerism analysis revealed full donor hematopoiesis, cerebral vasculopathy had nearly disappeared, and the patient had no medical treatment.

\section{Bone marrow transplantation and $\mathrm{AlH}$}

Vento et al. [90] suggested that if standard immunosuppressive treatment fails, adoptive cellular immunotherapy may be a viable option for people with AIH. They presented a case report involving a 19-year-old man with 4 years history of AIH who tested negative for all viral hepatitis. In October 1991, he was diagnosed with acute lymphoblastic leukemia. His wholesome brother was chosen as an MLC-non-reactive BM donor who was HLA A-, HLA B-, and DR-matched. In January 1992, the patient got $6.8 \times 10^{8} \mathrm{BM}$ cells (which had been depleted of red blood cells) per $\mathrm{kg}$ (total $4.7 \times 10^{10}$ cells) following conditioning with fractionated whole body irradiation, etoposide, cyclophosphamide, and fractionated total lymphoid irradiation. Anti-CDW52 rat antihuman lymphocyte antibody was used to remove $\mathrm{T}$ cells. As part of a strategy designed to increase the donor $\mathrm{T}$ lymphocyte fight against residual host leukemia cells.

There was no anti-GvHD prophylaxis provided after the BMT, but the patient suffered from grade 1 acute cutaneous GvHD following receiving the donor $\mathrm{T}$ cells and was medicated with prednisolone and cyclosporin A orally. From 1 month following BMT, asialoglycoprotein receptor specific suppressor-inducer T-cell activity has returned to normal on 27 occasions, and T-cell immunity to the same antigen has been undetected. In April 1993, histology of the liver revealed that it had improved (Knodell score 4), and in April 1996, liver histology indicated resolution of liver disease (score 1), and the leukemia did not return.

Although it appears that immunosuppressive therapy for BMT generated $\mathrm{AH}$ remission in this patient, the sustained remission, and the normalization of ASGPRspecific suppressor-inducer T-cell activity after BMT, supposed that the suppressor function that was missing in this patient was supplied by the donor $\mathrm{T}$ cells. It's possible that clonal elimination of the liver-damaging helper $\mathrm{T}$ cells has been accomplished (Table 2) [90].

\section{Future perspectives}

Few studies have been carried out into the effect of stem cells as therapy for AIH. More research is needed, with more efficient models, more standardized protocols, and longer duration, to exclude possible long-term side effects, before preclinical and clinical trials can be conducted.

MSC and EAH research has depended on the use of Con A-induced hepatitis and liver homogenate (S-100 emulsified in Freund's adjuvant) as models for EAH. Con A-induced hepatitis is a useful model for highly specific activation of $\mathrm{T}$ cells and used widely in research for investigating the role of T cells in $\mathrm{AIH}$, but it is acute hepatic injury model not chronic, also it is a cytokinedependent and antigen-independent. The use of liver homogenate for inducing hepatitis is a simple approach and has been widely used in the search for the mechanisms of AIH, but these models are induced by transferring of liver extracts to the animal body with a mostly unidentified composition [92]. There is therefore a need for better EAH models. Methods of administration, number and source of stem cells, toxicity, immune responses, development of embolus, tumorigenesis, and other adverse impact of MSCs should be controlled before the application of MSCs in clinical studies.

MSC-exosome therapy appears to be promising, and the use of these bodies may be able to assist in lowering the risk of MSCs administration [49]. However, further investigation is needed to determine toxicity caused by MSC-exosome therapy, either organ-specific or systemic, and their long-term adverse effects and efficacy. Consideration should be given to how to more effectively and conveniently extract exosomes. Methods for delivering exosomes more specifically into target areas must be developed [48]. Different passages of MSCs, as well as the state of the cells, can influence the production and composition of exosomes. For example, Xin et al. [93] have shown that MSC-exosomes subjected to ischemic tissues, possess large amounts of miRNAs (miR-133b). The discovery of the molecular composition of exosomes will require more research.

In conclusion, MSC treatment has shown to be promising in various $\mathrm{AIH}$ animal researches. However, to yet, no clinical investigations relying on MSC treatment have been conducted. Therefore, the clinically beneficial effect of MSCs in therapy of AIH needs approval. Therefore, further basic and clinical studies focused on stem cell therapies for AIH are required. The possible synergistic effects between stem cells and other immunomodulation compounds have not yet been tested. Also, the use of MSCs to aid HSCs trasplantation and to avoid graft failure requires further testing.

\section{Abbreviations}

EAH: Experimental autoimmune hepatitis; inj: Injection; IV: Intravenous; IP: Intraperitoneal; BM-MSCs: Bone marrow mesenchymal stem cells; CTLA4: Cytotoxic T cell antigen 4; IDO-1: Indoleamine 2,3-dioxygenase 1; PDL1: The ligand of PD-1 "Programmed death-1"; PBS: Phosphate buffer saline: AD-MSCs: Adipose-derived mesenchymal stem cells; MNC: Mononuclear cells; Con A: Concanavalin A; FasL: Fas ligand; IFN-y: Interferon-gamma;

IL: Interleukin; iNOS: Inducible nitric oxide synthase; JAK: Janus kinase; 
PGE2: Prostaglandin E2; STAT: Signal transducer and activator of transcription; LPS: Lipopolsaccharide; 3'-UTR: Untranslated region; Treg: Regulatory T cells; Th17: T helper 17 cells; TGF- $\beta$ : Transforming growth factor beta

\section{Acknowledgements}

Authors would like to thank Dr. Bassma Abdelaziz, Mansoura University for her support.

\section{Code availability}

Not applicable.

\section{Authors' contributions}

The article was written by $A L, A E, A B, A S, R S, A H$, and GS. AL and $A E$ contributed equally to the acquisition of the data and manuscript preparation. GS and AL contributed equally to the study design and critical review the manuscript. The authors read and approved the final manuscript.

\section{Funding}

Not applicable.

\section{Availability of data and materials}

All data presented in this review are totally available and present in the text.

\section{Declarations}

\section{Ethics approval and consent to participate}

Not applicable.

\section{Consent for publication}

Not applicable.

\section{Competing interests}

The authors declare that they have no competing interests.

\section{Author details}

${ }^{1}$ Biotechnology and Life Sciences Department, Faculty of Postgraduate Studies for Advanced Sciences (PSAS), Beni-Suef University, Beni-Suef 62511, Egypt. ${ }^{2}$ Department of Animal Histology and Anatomy, Faculty of Veterinary Medicine, Badr University in Cairo (BUC), Cairo, Egypt. ${ }^{3}$ Department of Immunology, Transplantology and Internal Diseases, Medical University of Warsaw, Nowogrodzka 59, 02-006 Warsaw, Poland. ${ }^{4}$ Department of Theriogenology, Faculty of Veterinary Medicine, Zagazig University, Zagazig 44511, Egypt. ${ }^{5}$ Department of Animal Production, College of Food and Agriculture Sciences, King Saud University, Riyadh 11451, Saudi Arabia. ${ }^{6}$ Tropical Medicine Department, Faculty of Medicine, Port Said University, Port Said, Egypt. ' Egyptian Liver Research Institute and Hospital (ELRIAH), Mansoura, Egypt. ${ }^{8}$ Hepatology and Gastroenterology Unit, Internal Medicine Department, Faculty of Medicine, Mansoura University, Mansoura, Egypt.

\section{Received: 9 April 2021 Accepted: 14 May 2021}

\section{Published online: 07 July 2021}

\section{References}

1. Mattner J. Genetic susceptibility to autoimmune liver disease. World J Hepatol. 2011;3(1):1-7. Epub 2011/02/11. https://doi.org/10.4254/wjh.v3.i1.1.

2. Zhou GP, Jiang YZ, Sun LY, Zhu ZJ. Therapeutic effect and safety of stem cell therapy for chronic liver disease: a systematic review and meta-analysis of randomized controlled trials. Stem cell Res Ther. 2020;11(1):1-19.

3. Liang J, Zhang H, Zhao C, Wang D, Ma X, Zhao S, et al. Effects of allogeneic mesenchymal stem cell transplantation in the treatment of liver cirrhosis caused by autoimmune diseases. Int J Rheum Dis. 2017;20(9):1219-26. Epub 2017/02/22. https://doi.org/10.1111/1756-185X.13015.

4. He C, Yang Y, Zheng K, Chen Y, Liu S, Li Y, et al. Mesenchymal stem cellbased treatment in autoimmune liver diseases: underlying roles, advantages and challenges. Ther Adv Chronic Dis. 2021;12:204062232199344. https:// doi.org/10.1177/2040622321993442

5. Brooks PM. Hematopoietic stem cell transplantation for autoimmune diseases. J Rheumatol Suppl. 1997;48:19-22 Epub 1997/05/01.

6. AdiwinataPawitan J. Exploring the most promising stem cell therapy in liver failure: a systematic review. Stem Cells Int. 2019;2019:1-15. https://doi.org/1 $0.1155 / 2019 / 2782548$.
7. Manns MP, Czaja AJ, Gorham JD, Krawitt EL, Mieli-Vergani G, Vergani D, et al. Diagnosis and management of autoimmune hepatitis. Hepatology. 2010; 51(6):2193-213. Epub 2010/06/01. https://doi.org/10.1002/hep.23584.

8. Liberal R, Grant CR, Mieli-Vergani G, Vergani D. Autoimmune hepatitis: a comprehensive review. J Autoimmun. 2013;41:126-39. Epub 2012/12/12. https://doi.org/10.1016/j.jaut.2012.11.002.

9. Hennes EM, Zeniya M, Czaja AJ, Pares A, Dalekos GN, Krawitt EL, et al. Simplified criteria for the diagnosis of autoimmune hepatitis. Hepatology. 2008;48(1):169-76. Epub 2008/06/10. https://doi.org/10.1002/hep.22322.

10. Gatselis NK, Zachou K, Koukoulis GK, Dalekos GN. Autoimmune hepatitis, one disease with many faces: etiopathogenetic, clinico-laboratory and histological characteristics. World J Gastroenterol. 2015;21(1):60-83. Epub 2015/01/13. https://doi.org/10.3748/wjg.v21.i1.60.

11. Mieli-Vergani G, Vergani D, Czaja AJ, Manns MP, Krawitt EL, Vierling JM, et al. Autoimmune hepatitis. Nat Rev Dis Primers. 2018;4(1):18017. Epub 2018/04/ 13. https://doi.org/10.1038/nrdp.2018.17.

12. Selvarajah V, Montano-Loza AJ, Czaja AJ. Systematic review: managing suboptimal treatment responses in autoimmune hepatitis with conventional and nonstandard drugs. Aliment Pharmacol Ther. 2012;36(8):691-707. Epub 2012/09/15. https://doi.org/10.1111/apt.12042.

13. Christen U. Animal models of autoimmune hepatitis. Biochim Biophys Acta Mol basis Dis. 2019;1865(5):970-81. Epub 2018/06/02. https://doi.org/10.101 6/j.bbadis.2018.05.017.

14. Tiegs $G$, Hentschel J, Wendel A. A T cell-dependent experimental liver injury in mice inducible by concanavalin A. J Clin Invest. 1992;90(1):196-203. Epub 1992/07/01. https://doi.org/10.1172/JC1115836.

15. Nelson SD, Pearson PG. Covalent and noncovalent interactions in acute lethal cell injury caused by chemicals. Annu Rev Pharmacol Toxicol. 1990;30:169-95. Epub 1990/01/01. https://doi.org/10.1146/annurev.pa.30.040190.001125.

16. Heymann F, Hamesch K, Weiskirchen R, Tacke F. The concanavalin A model of acute hepatitis in mice. Lab Anim. 2015;49(1 Suppl):12-20. Epub 2015/04/ 04. https://doi.org/10.1177/0023677215572841.

17. Kuriki J, Murakami H, Kakumu S, Sakamoto N, Yokochi T, Nakashima I, et al. Experimental autoimmune hepatitis in mice after immunization with syngeneic liver proteins together with the polysaccharide of Klebsiella pneumoniae. Gastroenterology. 1983;84(3):596-603. Epub 1983/03/01. https://doi.org/10.1016/0016-5085(83)90085-9.

18. Lohse AW, Dienes HP. Meyer zum Buschenfelde KH. Suppression of murine experimental autoimmune hepatitis by T-cell vaccination or immunosuppression. Hepatology. 1998;27(6):1536-43. Epub 1998/06/10. https://doi.org/10.1002/hep.510270611.

19. Shi Y, Wang Y, Li Q, Liu K, Hou J, Shao C. Immunoregulatory mechanisms of mesenchymal stem and stromal cells in inflammatory diseases. Nat Rev Nephrol. 2018;14(8):493-507. Epub 2018/06/14. https://doi.org/10.1038/s41 581-018-0023-5.

20. Ferraro GA, Mizuno H, Pallua N. Adipose stem cells: from bench to bedside. Stem Cells Int. 2016;2016:6484038 Epub 2016/04/19.

21. Lotfy A, Salama M, Zahran F, Jones E, Badawy A, Sobh M. Characterization of mesenchymal stem cells derived from rat bone marrow and adipose tissue: a comparative study. Int J Stem Cells. 2014;7(2):135-42. Epub 2014/12/05. https://doi.org/10.15283/ijsc.2014.7.2.135.

22. Lotfy A, El-Sherbiny YM, Cuthbert R, Jones E, Badawy A. Comparative study of biological characteristics of mesenchymal stem cells isolated from mouse bone marrow and peripheral blood. Biomed Rep. 2019;11(4):165-70. Epub 2019/10/01. https://doi.org/10.3892/br.2019.1236.

23. Gaber T, Schonbeck K, Hoff H, Tran CL, Strehl C, Lang A, et al. CTLA-4 mediates inhibitory function of mesenchymal stem/stromal cells. Int J Mol Sci. 2018;19(8) Epub 2018/08/09.

24. Webb GJ, Hirschfield GM, Krawitt EL, Gershwin ME. Cellular and molecular mechanisms of autoimmune hepatitis. Annu Rev Pathol. 2018;13(1):247-92. Epub 2017/11/16. https://doi.org/10.1146/annurev-pathol-020117-043534.

25. Davies LC, Heldring N, Kadri N, Le Blanc K. Mesenchymal stromal cell secretion of programmed death-1 ligands regulates T cell mediated immunosuppression. Stem Cells. 2017;35(3):766-76. Epub 2016/10/27. https://doi.org/10.1002/stem.2509.

26. Meesuk L, Tantrawatpan C, Kheolamai P, Manochantr S. The immunosuppressive capacity of human mesenchymal stromal cells derived from amnion and bone marrow. Biochem Biophysics Rep. 2016;8:34-40. Epub 2017/09/29. https://doi.org/10.1016/j.bbrep.2016.07.019.

27. Lim JY, Kim BS, Ryu DB, Kim TW, Park G, Min CK. The therapeutic efficacy of mesenchymal stromal cells on experimental colitis was improved by the 
IFN-gamma and poly(l:C) priming through promoting the expression of indoleamine 2,3-dioxygenase. Stem Cell Res Ther. 2021;12(1):37. Epub 2021/ 01/09. https://doi.org/10.1186/s13287-020-02087-7.

28. Jiang W, Xu J. Immune modulation by mesenchymal stem cells. Cell Prolif. 2020;53(1):e12712. Epub 2019/11/16. https://doi.org/10.1111/cpr.12712.

29. Atsuta I, Liu S, Miura Y, Akiyama K, Chen C, An Y, et al. Mesenchymal stem cells inhibit multiple myeloma cells via the Fas/Fas ligand pathway. Stem Cell Res Ther. 2013;4(5):111. Epub 2013/09/13. https://doi.org/10.1186/ scrt322.

30. Luz-Crawford P, Kurte M, Bravo-Alegria J, Contreras R, Nova-Lamperti E, Tejedor G, et al. Mesenchymal stem cells generate a CD4+CD25+Foxp3+ regulatory $T$ cell population during the differentiation process of Th1 and Th17 cells. Stem Cell Res Ther. 2013;4(3):65. Epub 2013/06/06. https://doi. org/10.1186/scrt216

31. English K, Ryan JM, Tobin L, Murphy MJ, Barry FP, Mahon BP. Cell contact, prostaglandin $\mathrm{E}(2)$ and transforming growth factor beta 1 play nonredundant roles in human mesenchymal stem cell induction of CD4+ CD25(High) forkhead box P3+ regulatory T cells. Clin Exp Immunol. 2009; 156(1):149-60. Epub 2009/02/13. https://doi.org/10.1111/j.1365-2249.2009.03 874.x

32. Melief SM, Schrama E, Brugman MH, Tiemessen MM, Hoogduijn MJ, Fibbe WE, et al. Multipotent stromal cells induce human regulatory T cells through a novel pathway involving skewing of monocytes toward anti-inflammatory macrophages. Stem Cells. 2013;31(9):1980-91. Epub 2013/05/29. https://doi. org/10.1002/stem.1432.

33. Duffy MM, Pindjakova J, Hanley SA, McCarthy C, Weidhofer GA, Sweeney EM, et al. Mesenchymal stem cell inhibition of T-helper 17 celldifferentiation is triggered by cell-cell contact and mediated by prostaglandin E2 via the EP4 receptor. Eur J Immunol. 2011;41(10):2840-51. Epub 2011/06/29. https://doi.org/10.1002/eji.201141499.

34. Wang Y, Chen X, Cao W, Shi Y. Plasticity of mesenchymal stem cells in immunomodulation: pathological and therapeutic implications. Nat Immunol. 2014;15(11):1009-16. Epub 2014/10/21. https://doi.org/10.1038/ ni.3002.

35. Munir H, McGettrick HM. Mesenchymal stem cell therapy for autoimmune disease: risks and rewards. Stem Cells Dev. 2015;24(18):2091-100. Epub 2015/06/13. https://doi.org/10.1089/scd.2015.0008.

36. Frenette PS, Pinho S, Lucas D, Scheiermann C. Mesenchymal stem cell: keystone of the hematopoietic stem cell niche and a stepping-stone for regenerative medicine. Annu Rev Immunol. 2013;31(1):285-316. Epub 2013/ 01/10. https://doi.org/10.1146/annurev-immunol-032712-095919.

37. El-Gendy H, Hawass SE, Awad M, Mohsen MA, Amin M, Abdalla HA, et al. Comparative study between human mesenchymal stem cells and etanercept as immunomodulatory agents in rat model of rheumatoid arthritis. Immunol Res. 2020;68(5):255-68. Epub 2020/08/01. https://doi.org/1 0.1007/s12026-020-09132-w.

38. Ren G, Zhang L, Zhao X, Xu G, Zhang Y, Roberts Al, et al. Mesenchymal stem cell-mediated immunosuppression occurs via concerted action of chemokines and nitric oxide. Cell Stem Cell. 2008;2(2):141-50. Epub 2008/ 03/29. https://doi.org/10.1016/j.stem.2007.11.014.

39. Lotfy A, Ali NS, Abdelgawad M, Salama M. Mesenchymal stem cells as a treatment for multiple sclerosis: a focus on experimental animal studies. Rev Neurosci. 2020;31(2):161-79. Epub 2019/10/13. https://doi.org/10.1515/ revneuro-2019-0040.

40. Lee HY, Hong IS. Double-edged sword of mesenchymal stem cells: cancerpromoting versus therapeutic potential. Cancer Sci. 2017;108(10):1939-46. Epub 2017/08/02. https://doi.org/10.1111/cas.13334.

41. Ren G, Chen X, Dong F, Li W, Ren X, Zhang Y, et al. Concise review: mesenchymal stem cells and translational medicine: emerging issues. Stem Cells Transl Med. 2012;1 (1):51-8. Epub 2012/12/01. https://doi.org/10.5966/ sctm.2011-0019.

42. Bian L, Guo ZK, Wang HX, Wang JS, Wang H, Li QF, et al. In vitro and in vivo immunosuppressive characteristics of hepatocyte growth factor-modified murine mesenchymal stem cells. In Vivo. 2009;23(1):21-7 Epub 2009/04/17.

43. Li A, Zhang Q, Jiang J, Yuan G, Feng Y, Hao J, et al. Co-transplantation of bone marrow stromal cells transduced with IL-7 gene enhances immune reconstitution after allogeneic bone marrow transplantation in mice. Gene Ther. 2006;13(15):1178-87. Epub 2006/04/07. https://doi.org/10.1038/s.gt.33 02741.

44. Min CK, Kim BG, Park G, Cho B, Oh IH. IL-10-transduced bone marrow mesenchymal stem cells can attenuate the severity of acute graft-versus- host disease after experimental allogeneic stem cell transplantation. Bone Marrow Transplant. 2007:39(10):637-45. Epub 2007/03/21. https://doi.org/1 0.1038/sj.bmt.1705644.

45. Qi H, Chen G, Huang Y, Si Z, Li J. Foxp3-modified bone marrow mesenchymal stem cells promotes liver allograft tolerance through the generation of regulatory T cells in rats. J Transl Med. 2015;13(1):274. Epub 2015/08/22. https://doi.org/10.1186/s12967-015-0638-2.

46. Chen Y, Chen S, Liu LY, Zou ZL, Cai YJ, Wang JG, et al. Mesenchymal stem cells ameliorate experimental autoimmune hepatitis by activation of the programmed death 1 pathway. Immunol Lett. 2014;162(2 Pt B):222-8 Epub 2014/12/03.

47. Wang W, Guo H, Li H, Yan Y, Wu C, Wang X, et al. Interleukin-35 genemodified mesenchymal stem cells protect concanavalin A-induced fulminant hepatitis by decreasing the interferon gamma level. Hum Gene Ther. 2018;29(2):234-41. Epub 2017/10/22. https://doi.org/10.1089/hum.201 7.171

48. Chen L, Lu FB, Chen DZ, Wu JL, Hu ED, Xu LM, et al. BMSCs-derived miR223-containing exosomes contribute to liver protection in experimental autoimmune hepatitis. Mol Immunol. 2018;93:38-46. Epub 2017/11/18. https://doi.org/10.1016/.jmolimm.2017.11.008.

49. Lu FB, Chen DZ, Chen L, Hu ED, Wu JL, Li H, et al. Attenuation of experimental autoimmune hepatitis in mice with bone mesenchymal stem cell-derived exosomes carrying microRNA-223-3p. Mol Cell. 2019;42(12):90618. Epub 2019/12/13. https://doi.org/10.14348/molcells.2019.2283.

50. Zhao N, Li H, Yan Y, Jiang R, He X. Mesenchymal stem cells overexpressing IL-35 effectively inhibit CD4(+) T cell function. Cell Immunol. 2017;312:61-6. Epub 2016/12/21. https://doi.org/10.1016/j.cellimm.2016.12.001.

51. Tkach M, Thery C. Communication by extracellular vesicles: where we are and where we need to go. Cell. 2016;164(6):1226-32. Epub 2016/03/12. https://doi.org/10.1016/j.cell.2016.01.043.

52. Shiha G, Nabil A, Lotfy A, Soliman R, Hassan AA, Ali IS, et al. Antifibrotic effect of combination of nilotinib and stem cell-conditioned media on CCl4-induced liver fibrosis. Stem Cells Int. 2020;2020:6574010 Epub 2020/02/ 25.

53. Xin H, Li Y, Liu Z, Wang X, Shang X, Cui Y, et al. MiR-133b promotes neural plasticity and functional recovery after treatment of stroke with multipotent mesenchymal stromal cells in rats via transfer of exosome-enriched extracellular particles. Stem Cells. 2013;31(12):2737-46. Epub 2013/05/01. https://doi.org/10.1002/stem.1409.

54. Mohamed Abouelkheir DAE, Saad M-A, Abdelrahman KM, Sobh M-A, Lotfy A, Sobh MA. Mesenchymal stem cells versus their conditioned medium in the treatment of cisplatin-induced acute kidney injury: evaluation of efficacy and cellular side effects. Int J Clin Exp Med. 2016;9(12):23222-34.

55. Sadallah S, Eken C, Schifferli JA. Ectosomes as modulators of inflammation and immunity. Clin Exp Immunol. 2011;163(1):26-32. Epub 2010/11/03. https://doi.org/10.1111/j.1365-2249.2010.04271.x.

56. Kordelas L, Rebmann V, Ludwig AK, Radtke S, Ruesing J, Doeppner TR, et al. MSC-derived exosomes: a novel tool to treat therapy-refractory graft-versushost disease. Leukemia. 2014;28(4):970-3. Epub 2014/01/22. https://doi.org/1 0.1038/leu.2014.41.

57. Tan CY, Lai RC, Wong W, Dan YY, Lim SK, Ho HK. Mesenchymal stem cellderived exosomes promote hepatic regeneration in drug-induced liver injury models. Stem Cell Res Ther. 2014;5(3):76. Epub 2014/06/12. https:// doi.org/10.1186/scrt465.

58. Shigemoto-Kuroda T, Oh JY, Kim DK, Jeong HJ, Park SY, Lee HJ, et al. MSCderived extracellular vesicles attenuate immune responses in two autoimmune murine models: type 1 diabetes and uveoretinitis. Stem Cell Rep. 2017;8(5):1214-25. Epub 2017/05/13. https://doi.org/10.1016/j.stemcr.2 017.04.008.

59. Bobrie A, Colombo M, Raposo G, Thery C. Exosome secretion: molecular mechanisms and roles in immune responses. Traffic. 2011;12(12):1659-68. Epub 2011/06/08. https://doi.org/10.1111/j.1600-0854.2011.01225.x.

60. Till JE, Mc CE. A direct measurement of the radiation sensitivity of normal mouse bone marrow cells. Radiat Res. 1961;14(2):213-22. Epub 1961/02/01. https://doi.org/10.2307/3570892.

61. Lee JY, Hong SH. Hematopoietic stem cells and their roles in tissue regeneration. Int J Stem Cells. 2020;13(1):1-12. Epub 2020/01/01. https://doi. org/10.15283/ijsc19127.

62. Shlomchik MJ, Craft JE, Mamula MJ. From T to B and back again: positive feedback in systemic autoimmune disease. Nat Rev Immunol. 2001;1 (2):14753. Epub 2002/03/22. https://doi.org/10.1038/35100573. 
63. Alexander T, Bondanza A, Muraro PA, Greco R, Saccardi R, Daikeler T, et al. $\mathrm{SCT}$ for severe autoimmune diseases: consensus guidelines of the European Society for Blood and Marrow Transplantation for immune monitoring and biobanking. Bone Marrow Transplant. 2015;50(2):173-80. Epub 2014/11/12. https://doi.org/10.1038/bmt.2014.251.

64. Snowden JA, Saccardi R, Allez M, Ardizzone S, Arnold R, Cervera R, et al. Haematopoietic SCT in severe autoimmune diseases: updated guidelines of the European Group for Blood and Marrow Transplantation. Bone Marrow Transplant. 2012;47(6):770-90. Epub 2011/10/18. https://doi.org/10.1038/ bmt.2011.185.

65. Cohen JA, Baldassari LE, Atkins HL, Bowen JD, Bredeson C, Carpenter PA, et al. Autologous hematopoietic cell transplantation for treatment-refractory relapsing multiple sclerosis: position statement from the American Society for Blood and Marrow Transplantation. Biol Blood Marrow Transplant. 2019; 25(5):845-54. Epub 2019/02/23. https://doi.org/10.1016/j.bbmt.2019.02.014.

66. Sullivan KM, Majhail NS, Bredeson C, Carpenter PA, Chatterjee S, Crofford L, et al. Systemic sclerosis as an indication for autologous hematopoietic cell transplantation: position statement from the American Society for Blood and Marrow Transplantation. Biol Blood Marrow Transplant. 2018;24(10): 1961-4. Epub 2018/06/29. https://doi.org/10.1016/j.bbmt.2018.06.025.

67. Ng SA, Sullivan KM. Application of stem cell transplantation in autoimmune diseases. Curr Opin Hematol. 2019;26(6):392-8. Epub 2019/09/07. https://doi. org/10.1097/MOH.0000000000000531.

68. Daikeler T, Labopin M, Di Gioia M, Abinun M, Alexander T, Miniati I, et al. Secondary autoimmune diseases occurring after HSCT for an autoimmune disease: a retrospective study of the EBMT Autoimmune Disease Working Party. Blood. 2011;118(6):1693-8. Epub 2011/05/21. https://doi.org/10.1182/ blood-2011-02-336156

69. Snowden JA, Badoglio M, Labopin M, Giebel S, McGrath E, Marjanovic Z, et al. Evolution, trends, outcomes, and economics of hematopoietic stem cell transplantation in severe autoimmune diseases. Blood Adv. 2017;1(27): 2742-55. Epub 2018/01/04. https://doi.org/10.1182/bloodadvances.201701 0041.

70. Francisco LM, Sage PT, Sharpe AH. The PD-1 pathway in tolerance and autoimmunity. Immunol Rev. 2010;236(1):219-42. Epub 2010/07/20. https:// doi.org/10.1111/j.1600-065X.2010.00923.x.

71. Collison LW, Workman CJ, Kuo TT, Boyd K, Wang Y, Vignali KM, et al. The inhibitory cytokine IL-35 contributes to regulatory T-cell function. Nature. 2007;450(7169):566-9. Epub 2007/11/23. https://doi.org/10.1038/nature063 06.

72. Huang A, Cheng L, He M, Nie J, Wang J, Jiang K. Interleukin-35 on B cell and T cell induction and regulation. J Inflamm (Lond). 2017;14:16 Epub 2017/08/11.

73. Gao P, Su Z, Lv X, Zhang J. Interluekin-35 in asthma and its potential as an effective therapeutic agent. Mediat Inflamm. 2017;2017:5931865 Epub 2017/ 05/30.

74. Guan SY, Leng RX, Khan MI, Qureshi H, Li XP, Ye DQ, et al. Interleukin-35: a potential therapeutic agent for autoimmune diseases. Inflammation. 2017; 40(1):303-10. Epub 2016/10/04. https://doi.org/10.1007/s10753-016-0453-9.

75. Vande Walle L, Lamkanfi M. Pyroptosis. Curr Biol. 2016;26(13):R568-R72. Epub 2016/07/13. https://doi.org/10.1016/j.cub.2016.02.019.

76. Lamkanfi M, Dixit VM. Mechanisms and functions of inflammasomes. Cell. 2014;157(5):1013-22. Epub 2014/05/27. https://doi.org/10.1016/j.cell.2014.04. 007.

77. Martin BN, Wang C, Zhang CJ, Kang Z, Gulen MF, Zepp JA, et al. T cellintrinsic ASC critically promotes $\mathrm{T}(\mathrm{H}) 17$-mediated experimental autoimmune encephalomyelitis. Nat Immunol. 2016;17(5):583-92. Epub 2016/03/22. https://doi.org/10.1038/ni.3389

78. Gris D, Ye Z, locca HA, Wen H, Craven RR, Gris P, et al. NLRP3 plays a critical role in the development of experimental autoimmune encephalomyelitis by mediating Th1 and Th17 responses. J Immunol. 2010;185(2):974-81. Epub 2010/06/25. https://doi.org/10.4049/jimmunol.0904145.

79. Chen Z, Laurence A, O'Shea JJ. Signal transduction pathways and transcriptional regulation in the control of Th17 differentiation. Semin Immunol. 2007;19(6):400-8. Epub 2008/01/02. https://doi.org/10.1016/j. smim.2007.10.015.

80. Bettelli E, Carrier Y, Gao W, Korn T, Strom TB, Oukka M, et al. Reciprocal developmental pathways for the generation of pathogenic effector $\mathrm{TH} 17$ and regulatory T cells. Nature. 2006;441(7090):235-8. Epub 2006/05/02. https://doi.org/10.1038/nature04753.
81. Hammerich L, Heymann F, Tacke F. Role of IL-17 and Th17 cells in liver diseases. Clin Dev Immunol. 2011;2011:345803 Epub 2011/01/05.

82. Deknuydt F, Bioley G, Valmori D, Ayyoub M. IL-1 beta and IL-2 convert human Treg into T(H)17 cells. Clin Immunol. 2009;131(2):298-307. Epub 2009/02/13. https://doi.org/10.1016/j.clim.2008.12.008.

83. An Haack I, Derkow K, Riehn M, Rentinck MN, Kuhl AA, Lehnardt S, et al. The role of regulatory CD4 T cells in maintaining tolerance in a mouse model of autoimmune hepatitis. PLoS One. 2015;10(11):e0143715. Epub 2015/11/26. https://doi.org/10.1371/journal.pone.0143715.

84. Eisenstein EM, Williams CB. The T(reg)/Th17 cell balance: a new paradigm for autoimmunity. Pediatr Res. 2009;65(5 Pt 2):26R-31R. Epub 2009/02/17. https://doi.org/10.1203/PDR.0b013e31819e76c7.

85. Kato M, Ikeda N, Matsushita E, Kaneko S, Kobayashi K. Involvement of IL-10, an anti-inflammatory cytokine in murine liver injury induced by concanavalin A. Hepatol Res. 2001;20(2):232-43. Epub 2001/05/12. https:// doi.org/10.1016/S1386-6346(00)00137-6.

86. Peiseler M, Sebode M, Franke B, Wortmann F, Schwinge D, Quaas A, et al. FOXP3+ regulatory $T$ cells in autoimmune hepatitis are fully functional and not reduced in frequency. J Hepatol. 2012;57(1):125-32. Epub 2012/03/20. https://doi.org/10.1016/j.jhep.2012.02.029.

87. Wang L, Du H, Liu Y, Ma X, Zhang W. Chinese medicine bu xu hua yu recipe for the regulation of treg/th17 ratio imbalance in autoimmune hepatitis. Evid Based Complement Alternat Med. 2015;2015:461294 Epub 2015/05/16.

88. Zhao L, Tang Y, You Z, Wang Q, Liang S, Han X, et al. Interleukin-17 contributes to the pathogenesis of autoimmune hepatitis through inducing hepatic interleukin-6 expression. PLoS One. 2011;6(4):e18909. Epub 2011/04/ 29. https://doi.org/10.1371/journal.pone.0018909.

89. Calore E, Marzollo A, Cananzi M, Pizzi M, Rugge M, Rossin S, et al. Haploidentical stem cell transplantation cures autoimmune hepatitis and cerebrovascular disease in a patient with sickle cell disease. Bone Marrow Transplant. 2018;53(5):644-6. Epub 2018/01/18. https://doi.org/10.1038/s414 09-017-0065-5.

90. Vento S, Cainelli F, Renzini C, Ghironzi G, Concia E. Resolution of autoimmune hepatitis after bone-marrow transplantation. Lancet. 1996; 348(9026):544-5. Epub 1996/08/24. https://doi.org/10.1016/S0140-673 6(05)64700-9.

91. Marzollo A, Calore E, Tumino M, Pillon M, Gazzola MV, Destro R, et al. Treosulfan-based conditioning regimen in sibling and alternative donor hematopoietic stem cell transplantation for children with sickle cell disease. Mediterr J Hematol Infect Dis. 2017;9(1):e2017014. Epub 2017/03/16. https:// doi.org/10.4084/mjhid.2017.014

92. Liu SP, Bian ZH, Zhao ZB, Wang J, Zhang W, Leung PSC, et al. Animal models of autoimmune liver diseases: a comprehensive review. Clin Rev Allergy Immunol. 2020;58(2):252-71. Epub 2020/02/23. https://doi.org/10.1 007/s12016-020-08778-6.

93. Xin H, Li Y, Buller B, Katakowski M, Zhang Y, Wang X, et al. Exosomemediated transfer of miR-133b from multipotent mesenchymal stromal cells to neural cells contributes to neurite outgrowth. Stem Cells. 2012;30(7): 1556-64. Epub 2012/05/19. https://doi.org/10.1002/stem.1129.

\section{Publisher's Note}

Springer Nature remains neutral with regard to jurisdictional claims in published maps and institutional affiliations. 